\title{
Developing Streamflow Model for Sustainable Rural Water Supply at Ndimoko, Imo State, Nigeria
}

By

\author{
${ }^{1}$ B. C. Okoro and ${ }^{2}$ R. A. Uzoukwu
}

\begin{abstract}
Streamflow model of Imo River at Ndimoko was developed using statistical method of least squares. High and positive values of coefficient of correlation (r) of 0.953 and coefficient of determination $\left(\mathrm{r}^{2}\right)$ of 0.908 were obtained. The standard error of estimate $\left(\mathrm{S}_{\mathrm{Q} . \mathrm{h}}\right)$ has small value of 1.82 indicating that the regression model fits the data. The model represents the nonlinear relationship between annual maximum discharge and annual maximum stage. The model developed is necessary for the design of dam, estimation of the size of reservoir, water conservation methods, potable water supply, flood estimation, wild life protection and recreational use of water in the locality. In other words, this model will play an important role in ensuring that future planning and management of water in a rural area is scientifically based and efficiently made. Recommendations are made that hydrologic modeling be applied in water resources planning, design and management activities for environmental sustainability.
\end{abstract}

Keywords: Maximum Stage, Maximum Discharge, Coefficient of Correlation, Coefficient of Determination, Water Supply.

\section{Introduction}

Water resources engineers and hydrologists in the developing and underdeveloped countries are often posed with lack of adequate hydrologic data and invariably lack of hydrologic modeling which are necessary for the analysis and design of hydrologic projects (Ojha et al., 2008; Viessman and Lewis, 2008; Raghunath, 2006; Sonuga, 1990). A proper understanding of flow regime of river is essential for channel design and the estimation of flood discharges such structure could tolerate (Awokola and Martins, 2001).

The growing population is putting enormous pressure on limited fresh water resources, and is forcing a revisit and reassessment of how water resources is managed in a region.

${ }^{1}$ Department of Civil Engineering, Federal University of Technology Owerri, Imo State, Nigeria. ${ }^{2}$ Department of Civil Engineering Technology, Federal Polytechnic Nekede Owerri, Imo State, Nigeria. 
Water accounting, which is identifying, quantifying and reporting information of water flow in a system, is the first step towards formulating productive and sustainable water management strategies in a region (Singh et al., 2009; Suresh, 2012; Garg, 2012).

The relationship between stage $(\mathrm{m})$ and the corresponding discharge $\left(\mathrm{m}^{3} / \mathrm{s}\right)$ is an

exponential function (Ojha et al., 2008). In this study, regression modeling was adopted to fit streamflow data of Imo River at Ndimoko for eleven years duration (1978-1988).

\section{Methodology}

\subsection{The Study Area and Data Collection}

Imo River at Ndimoko constitutes the study area. Ndimoko is located at Okgiwe in Imo State of Nigeria. Ndimoko stream flow gauging station is located on latitude $05^{\prime} 52^{\prime} \mathrm{N}$ and longitude $07^{\prime} 15^{\prime} \mathrm{E}$ and catchment area of $160 \mathrm{sq} \mathrm{km}$ (See Fig 1). The streamflow data utilized in this research where obtained from Anambra Imo River Basin Development Authority, located at Agbala, along Owerri-Aba road in Imo State of Nigeria.

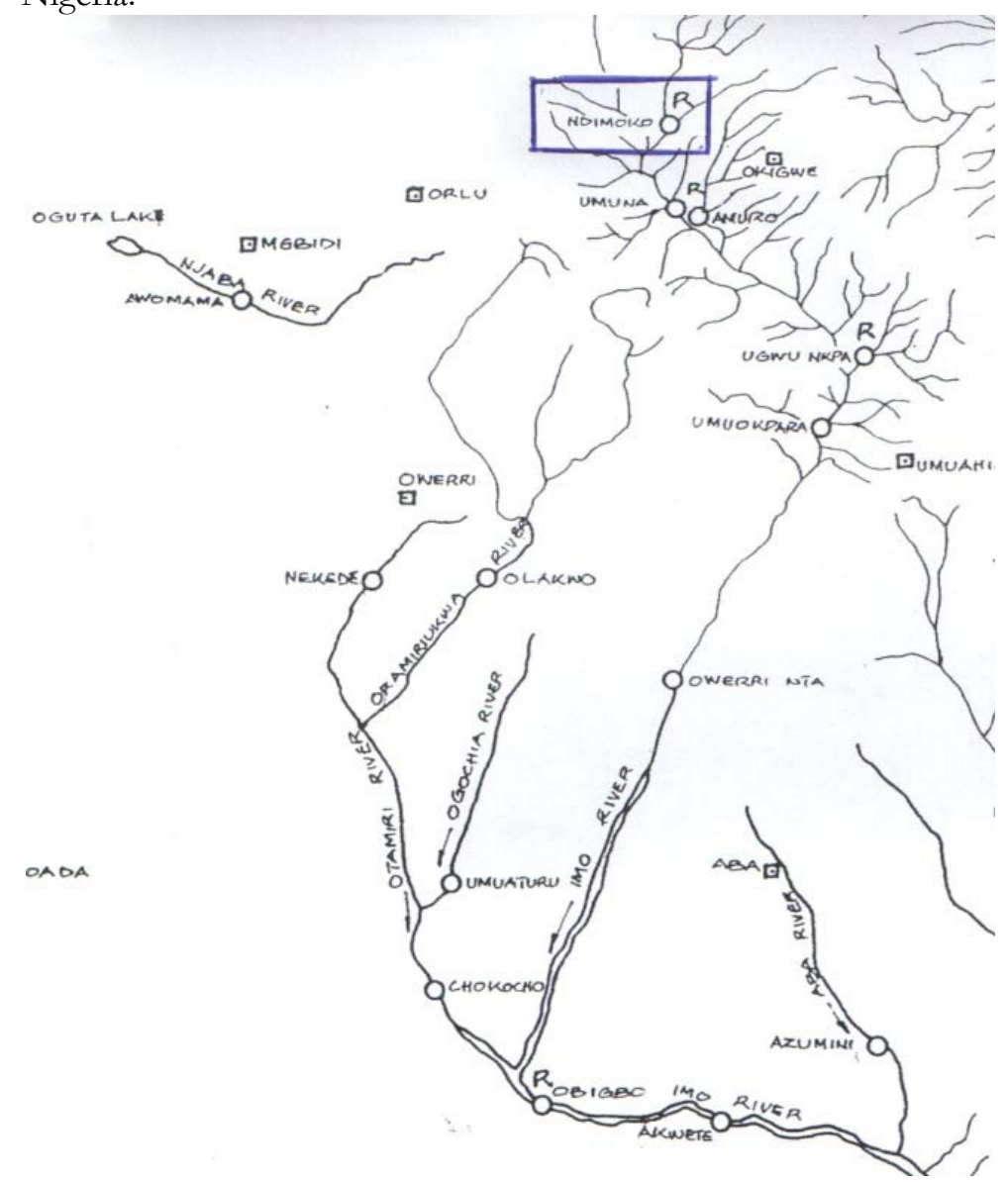

Fig. 1 Imo River Basin - Showing Ganging Station (Source: AIRBDA, 1984) 


\subsection{Model Development and calibration}

The mathematical representation of the relationship between the stage $(\mathrm{h})$ and the corresponding discharge $(\mathrm{Q})$ can be expressed as:

$\mathrm{Q}=\mathrm{k}(\mathrm{h})^{\mathrm{b}}$.

where $\mathrm{k}$ and $\mathrm{b}$ are constants for any stream gauging station (Ojha et al., 2008; Reddy, 2008 ;Arora, 2011). The above relationship is an exponential function which can be handled by transforming it to a straight line by using logarithms of the variables. Logarithmic transformation can also be avoided by fitting an exponential growth curve to actual data (Moore and McCabe, 1993). Regression modeling was adopted to fit available streamflow data obtained from the gauging station.

\section{Results and Discussions}

\subsection{Results}

The eleven years available record of annual maximum discharge and annual maximum stage of Imo River from Ndimoko streamflow gauging station (Table 1) were plotted. The computed output for regression is shown in Figure 2. With the values obtained, the regression modeling approach utilized the original data in model calibration and using coefficient of correlation, coefficient of determination and standard error of estimate as evaluation parameters for good curve fitting for the model.

Table 1

\begin{tabular}{|l|l|l|l|}
\hline S/N & Year & $\begin{array}{l}\text { Annual Maximum Stage }(\mathrm{h}) \\
(\mathrm{m})\end{array}$ & $\begin{array}{l}\text { Annual Maximum Discharge }\left(\mathrm{Q}_{\text {max. }}\right) \\
\left(\mathrm{m}^{3} / \mathrm{s}\right)\end{array}$ \\
\hline 1 & 1978 & 3.02 & 25.00 \\
\hline 2 & 1979 & 2.59 & 18.20 \\
\hline 3 & 1980 & 3.30 & 27.50 \\
\hline 4 & 1981 & 3.14 & 24.40 \\
\hline 5 & 1982 & 3.16 & 18.90 \\
\hline 6 & 1983 & 3.14 & 24.50 \\
\hline 7 & 1984 & 3.00 & 22.84 \\
\hline 8 & 1985 & 2.95 & 22.28 \\
\hline 9 & 1986 & 2.79 & 20.49 \\
\hline 10 & 1987 & 3.56 & 29.51 \\
\hline 11 & 1988 & 3.51 & 29.02 \\
\hline
\end{tabular}

Table 2 Imo River Streamflow Model at Ndimoko

\begin{tabular}{|l|l|r|}
\hline $\begin{array}{l}\text { Streamflow gauging } \\
\text { station }\end{array}$ & $\begin{array}{l}\text { Streamflow } \\
\mathbf{Q}=\mathrm{k}(\mathrm{h})^{\mathbf{b}}\end{array}$ & Model Evaluation Parameters * $^{+}$ \\
\hline Ndimoko & $\mathbf{Q}=4.423 \mathrm{~h}^{1.495}$ & $\mathbf{r}^{2}=0.908$ \\
& $\mathbf{r}=\mathbf{0 . 9 5 3}$ \\
& $\mathrm{S}_{\mathrm{Q} . \mathrm{h}}=1.82$ \\
\hline
\end{tabular}

${ }^{+}$Annual maximum stage is given in meter $(\mathrm{m})$ and annual maximum discharge in cubic meter per second $\left(\mathrm{m}^{3} / \mathrm{s}\right)$ 
* Model Evaluation Parameters

$\mathrm{r}^{2}=$ Coefficient of determination

$\mathrm{r}=$ Coefficient of correlation

$\mathrm{S}_{\mathrm{Q} . \mathrm{h}}=$ Standard error of estimate of discharge $(\mathrm{Q})$ on stage $(\mathrm{h})$.

\section{Ndimoko Streamflow Gauging Station}

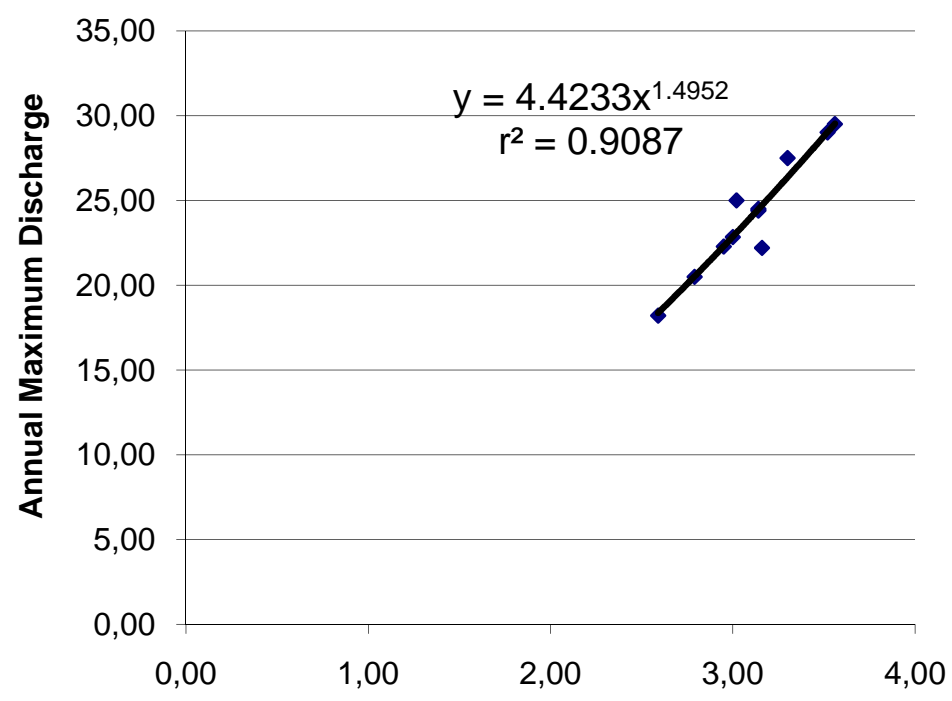

- Annual Max.

Discharge

Potenza (Annual Max. Discharge)

\section{Annual Maximum Stage}

Fig. 2 Plot of Annual Maximum Discharge versus Annual Maximum Stage at Ndimoko.

The streamflow model of Imo River at Ndimoko obtained from Figure 2 (using annual maximum discharge versus annual maximum stage curve) is shown in Table 2.

\subsection{Discussions}

Research result in Table 2 suggests that there is a good test of good fit of the regression analysis done using annual maximum discharge versus annual maximum stage. The coefficient of correlation (r) which summaries in one number the direction and the magnitude of correlation have very high value of 0.953 . The coefficient of determination $\left(\mathrm{r}^{2}\right)$ which is a measure of the variance explained in one variable (discharge) by its dependence on the other variable (stage) has very high and positive value of 0.908 . This implies that $91 \%$ of the total variance is explained. The standard error of estimate $\left(\mathrm{S}_{\mathrm{Q} . \mathrm{h}}\right)$ which is a measure of the scatter about the regression line of discharge $(\mathrm{Q})$ on stage $(\mathrm{h})$ 
has small value of 1.82 indicating that the regression model fits the data. A large $\mathrm{r}^{2}$ and a low standard error of estimate indicate a good fit of the regression analysis. The model provides the best-fit curve for the field data as well as confirming the nonlinear relationship between stage and discharge. It is necessary to state that the streamflow records extrapolated for fifty years period is similar to that of Table 2 and Fig.2. The model developed in this research will therefore be useful in determining the quantity of water required at any time in rural water supply and management. This in turn will lead to a sustainable water supply and effective conservation approaches in similar rural settings.

\section{Conclusion and Recommendations}

Since the model developed from the annual maximum discharge versus annual maximum stage from Ndimoko streamflow gauging station of Imo River have very high and positive values of coefficient of determination $\left(\mathrm{r}^{2}\right)$ of 0.908 and coefficient of correlation (r) of 0.953 , it could be concluded that its usage for water conservation and management practices in rural setting will yield desirous results. It can be seen that the model developed is necessary for the design of dam(s), estimation of the size of reservoir (s) provision of potable water supply, design of flood control structures, construction of irrigation and wild life protection facilities in Ndimoko community. It can be concluded that, this model will play an important role in ensuring that future planning and water management in Ndimoko community is scientifically based and efficiently made so as to satisfy the needs of both human and natural systems. It is therefore recommended that in the face of present day global warming effect in the world today which causes overflow of rivers banks and flooding of cities and regions, the model should be used to assist in environmental sustainability of rural water use.

It is further recommended that the developed model be applied in water resources planning, design, and management activities for environmental sustainability for rural development.

\section{References}

AIRBDA Hydrological Year Book (1984) Department of Operations. Hydrology and Hyrogeology / Meterology Division. Anambra Imo River Basin Development Authority. Agbala Owerri Aba road.

Arora, k. R. (2011) Irrigation, Water Power and Water Resources Engineering. $4^{\text {th }}$ edition. Delhi: Standard Publisher Distributors.

Awokola, O. S. and Martins, O. (2001) "Regional Flood Frequency Analysis of Osun Drainage Basin, South-Western Nigeria" Nigerian Journal of Science. Vol. 35, pp. 37-44.

Garg, S. K. (2012) Hydrology and Water Resources Engineering. 16 th revised edition, Delhi: Khanna Publishers.

Moore, D. S. and McCabe, G. P. (1993) Introduction to the Practice of Statistics. $2^{\text {nd }}$ edition, New York: W.H. Freeman and Company. 
Ojha, C. S. P., Berndtsson, R. and Bhunya, P. (2008) Engineering Hydrology. India: Oxford University Press.

Raghunath, H. M. (2006) Hydrology .2nd edition, New Delhi: New Age International (P) $\quad$ Ltd. Publishers.

Reddy, R. J. (2008) A Text Book of Hydrology. 2nd edition, New Delhi: University Science Press.

Singh, R., Masheshvari, B. and Malano, H. M. (2009) "Developing a Conceptual Model for Water Accounting in Peri-urban Catchments. 18 $8^{\text {th }}$ world IMACS / MODSM Congress, Cairns. Australia 13-17 July 2009. pp. 3654-3660.

Sonuga, J. O. (1990) "Hydrological Decision Making for Design of Water Resources Systems" Proceedings of Nigerian National Committee for International Hydrological Programme (IHP), pp.30-44.

Suresh, R. (2012) Land and Water Management Principles. Delhi: A. K. Jain.

Viessman, W. and Lewis, G. L. (2008) Introduction to Hydrology. $5^{\text {th }}$ edition. New Delhi: Prentice-Hall of India Private Limited. 